(С Савельева Е.С., Прощина А.Е., 2012

УДК 591.437:597

\author{
ИММУНОГИСТОХИМИЧЕСКАЯ ОРГАНИЗАЦИЯ \\ ЭНДОКРИННОЙ ТКАНИ ПОДЖЕЛУДОЧНОЙ ЖЕЛЕЗЫ \\ НЕКОТОРЫХ ВИДОВ ЛУЧЕПЕРЫХ РЫБ (Actinopterigii)
}

\author{
Е.С. Савельева, А.Е. Прощъина
}

ФГБУ «Научно-исследовательский институт морфологии человека» РАМН, г. Москва

В работе исследована эндокринная ткань поджелудочной железы 10 видов лучеперых рыб (Actinopterigii). Инсулинсодержащие клетки у большинства изученных видов рыб (кроме A. Anguilla, E. Lucius, C. Carpio) имели сферическую форму. Глюкагонсодержащие и соматостатинсодержащие клетки у всех видов имели шиповидную форму с цитоплазматическими отростками, не встречающуюся у млекопитающих. Для большинства изученных видов рыб характерен плащевой (корковый) тип распределения клеток в островке, при котором инсулинсодержащие клетки - в центре, а глюкагонсодержащие - на периферии. У $A$. ruthenus в островках содержатся только инсулин-позитивные клетки; глюкагон- и соматостатинпозитивные клетки распределены вокруг островков, единичные клетки и небольшие кластеры рассеяны в ацинарный ткани. У A. Anguilla выявлены островки с лежащими на периферии инсулин-позитивными клетками и внутренней локализацией глюкагон-позитивных клеток. Обнаруженный полиморфизм островков и эндокринных клеток не могут быть объяснены биологией видов и типом питания.

Ключевые слова: рыбы, поджелудочная железа, иммуногистохимия, островки, эндокринные клетки.

Поджелудочная железа (ПЖ) исследована у относительно небольшого числа видов лучеперых рыб. В этой группе было выявлено большое разнообразие типов строения этого органа: от обособленной оформленной ПЖ до, так называемой, гепатопанкреас, где ткань ПЖ диффузно расположена в печени и простирается вдоль ее протоков [1]. Исследования эндокринной ткани ПЖ у Actinopterigii позволило установить существование разнообразных по своей форме и цитоархитектонике островков с четырьмя основными типами эндокринных клеток $[1 ; 13 ; 14]$.

До сих пор остается актуальным вопрос, по каким параметрам нужно сравнивать эндокринную ткань рыб. Уилсон и АлМахруки предположили, что следует изучать расположение, вариации размеров островков, степень ассоциации островковой и ацинарной ткани, а также расположение и форму эндокринных клеток [13]. С учетом этого подхода мы провели имунногистохимическое исследование для оценки эволюционноадаптивных закономерностей перестройки ПЖ лучеперых рыб.

Материалы и методы

В работе нами были использована ткань ПЖ 45 экземпляров следующих видов рыб: стерлядь (A. ruthenus L., 1758), угорь речной (A. anguilla L., 1758), радужная форель (S. irideus L., 1758), корюшка малоротая (H. olidus L., 1758), щука обыкновенная (E. lucius L., 1758), карп (C. carpio L., 1758), сазан (C. carpio L., 1758), обыкновенный сом (S. glanis L., 1758), панга́сиус или акулий сом (P. hypophthalmus S., 1878), оринокский сом или краснохвостый фрактоцефалус ( $P$. hemiliopterus Bl. \& S., 1801). 
Эвтаназия животных проводилась согласно международным правилам [5]. Гистологические серийные срезы поджелудочной железы рыб (5-10 мкм) окрашивали по Маллори, гематоксилинпикрофуксином (по Ван Гизону) и по Гроссо. При изучении эндокринных кле- ток ПЖ было предпринято иммуногистохимическое исследование на смежных срезах, по выявлению моноклональными и поликлональными антителами инсулина, глюкагона и соматостатина. Список использованных антител и разведения представлен в таблице 1.

Таблица 1

\section{Иммунореактивность к антителам различных видов рыб}

\begin{tabular}{|c|c|c|c|c|c|c|}
\hline \multirow[t]{2}{*}{$\begin{array}{c}\text { Вид \Название } \\
\text { рыб \антител }\end{array}$} & \multicolumn{3}{|c|}{ Антитела к инсулину } & \multicolumn{2}{|c|}{$\begin{array}{c}\text { Антитела } \\
\text { к глюкагону } \\
\end{array}$} & \multirow[b]{2}{*}{$\begin{array}{c}\text { Антитела к } \\
\text { соматостатину } \\
\text { кролик } \\
\text { поликл. } \\
\text { Abcam (1:750) }\end{array}$} \\
\hline & $\begin{array}{c}\text { Мышь } \\
\text { монокл. } \\
\text { Lab } \\
\text { Vision } \\
(1: 400) \\
\end{array}$ & $\begin{array}{c}\text { Кролик } \\
\text { поликл. } \\
\text { Sigma } \\
(1: 100)\end{array}$ & $\begin{array}{c}\text { Морск. } \\
\text { Свинки } \\
\text { Sigma } \\
(1: 300)\end{array}$ & $\begin{array}{c}\text { Мышь } \\
\text { монокл. } \\
\text { Sigma } \\
(1: 100)\end{array}$ & $\begin{array}{c}\text { Кролик } \\
\text { поликл. } \\
\text { Lab } \\
\text { Vision } \\
(1: 100) \\
\end{array}$ & \\
\hline $\begin{array}{l}\text { стерлядь } \\
\text { A.ruthenus }\end{array}$ & + & + & + & - & + & + \\
\hline угорь A.Anguilla & - & - & + & - & + & + \\
\hline форель S.irideus & - & + & + & - & + & + \\
\hline $\begin{array}{l}\text { корюшка } H \text {. } \\
\text { olidus }\end{array}$ & - & - & + & - & + & + \\
\hline щука E. Lucius & - & + & + & - & + & + \\
\hline $\begin{array}{l}\text { карп C. carpio } \\
\text { carpio }\end{array}$ & - & - & + & - & + & + \\
\hline сазан C.carpio & - & - & + & - & + & + \\
\hline сом S. Glanis & - & + & + & + & + & + \\
\hline $\begin{array}{l}\text { панга́сиус } \\
\text { P.hypophthalmus }\end{array}$ & - & + & + & - & + & + \\
\hline $\begin{array}{l}\text { сом } \\
\text { P.hemiliopterus }\end{array}$ & - & + & + & - & + & + \\
\hline
\end{tabular}

Результаты и их обсуждение

Хрящевые ганоиды (Chondrostei) и ангвиллоидные (Anguillomorpha), являются наиболее филогенетически древними группами среди Actinopterigii. ПЖ стерляди и угря как по нашим, так и по литера- турным данным образует компактный оформленный орган. Экзокринная ткань представлена ацинусами характерного для млекопитающих строения. Эндокринная ткань представлена в виде хорошо васкуляризованных скоплений эпителиальных 
клеток, рассеянных в толще железы [3; 4 ; 6]. Такие островки у стерляди отделены от экзокринной ткани небольшим количеством фибробластов, не образующих настоящей капсулы. В отличие от хрящевых ганоидов, у угря соединительная ткань формирует капсулу вокруг островков. Островки в ПЖ у стерляди небольшого размеpa (до 170 мкм диаметром). Принято считать, что у угрей нет ни основных островков, ни островковых скоплений (телец Брокмана) в отличие от более прогрессивных рыб [7]. Тем не менее, мы обнаружили островки различного размера: крупные (до 300 мкм диаметром), которые являются, по всей видимости, основными островками; более мелкие, добавочные островки; единичные эндокринные клетки и небольшие кластеры. В эндокринных клетках, как хрящевых ганоидов, так и ангвиллоидных рыб была выявлена позитивная реакция на все три исследуемых гормона. Клетки, иммунопозитивные к инсулину у стерляди, имеют эллипсовидную форму, организованы в шнуры или дольки расположенные по всему островку. Глюкагон- и соматостатин-позитивные клетки сконцентрированы вокруг островков. Эти клетки имеют неправильную форму и часто отростки. Были выявлены единичные инсулин, глюкагон- и соматостатин-содержащие клетки и небольшие кластеры, рассеянные в ацинарной ткани. У угря инсулинпозитивные клетки в отличие от стерляди имеют неправильную форму и сгруппированы в тяжи, которые лежат в толще островка и превалируют в периферических зонах. В тяжи группируются и глюкагони соматостатин-позитивные клетки, однако они распределены по всему объему островка (Рис. 1 - 3, А, В).

По литературным данным считается, что промежуточные ступени в эволюции основных островков костных рыб можно наблюдать у лососеобразных [1]. В исследованиях Винсента и Буке [2; 10] указывается на компактную форму ПЖ щуки и описано распределение В-клеток, по всей площади островков.

У радужной форели описаны панкреатические островки, некоторые из ко- торых достигают размера основных, собранные в конгломераты и окруженные экзокринными ацинусами $[9 ; 11 ; 12]$. Островки встречаются в жировой ткани, окружающей пилорические выросты и селезенку. Это скопление островков называют островковым органом [11] или основным тельцем [12]. По нашим данным, у форели и корюшки эндокринная ткань представлена отдельными мелкими островками и конгломератами ткани имеющей общую оболочку. Конгломераты значительного размера (до 1170 мкм), лежат компактно, а экзокринная ткань может внедряться с периферии островковоподобных структур в их центральные зоны. Инсулинпозитивные клетки округлой формы с редко встречающимися отростками локализованы в центре островковоподобных конгломератов заполняя островки практически целиком. Глюкагон-позитивные клетки неправильной формы отростчатые, расположены по периферии конгломератов. В небольших островках глюкагонпозитивные клетки наблюдаются по всей площади островков. Соматостатинпозитивные клетки неправильной формы, располагаются преимущественно по периферии островков и конгломератов. Образованный ими корковый слой значительно шире зоны глюкагон-позитивных клеток. Соматостатин-позитивные как и глюкагонпозитивные клетки встречаются и в центре островков образуя тяжи (Рис. $1-3, \Gamma$ ).

У отрядов Карпообразные Cypriniformes и Со́мообра́зные Siluriformes, наблюдается еще более рассеянное расположение островковой ткани, чем у лососеобразных. Эндокринная ткань представлена крупными островками (у карпа до 370 мкм; у сазана до 580 мкм диаметром) с единой соединительнотканной капсулой, а также островками меньшего размера. Инсулин-позитивные клетки у карпа и сазана расположены в центре островков, тогда как глюкагон-позитивные по периферии островка и лишь в некоторых случаях встречаются в центре; соматостатинпозитивные клетки располагаются в центре островков [8]. 

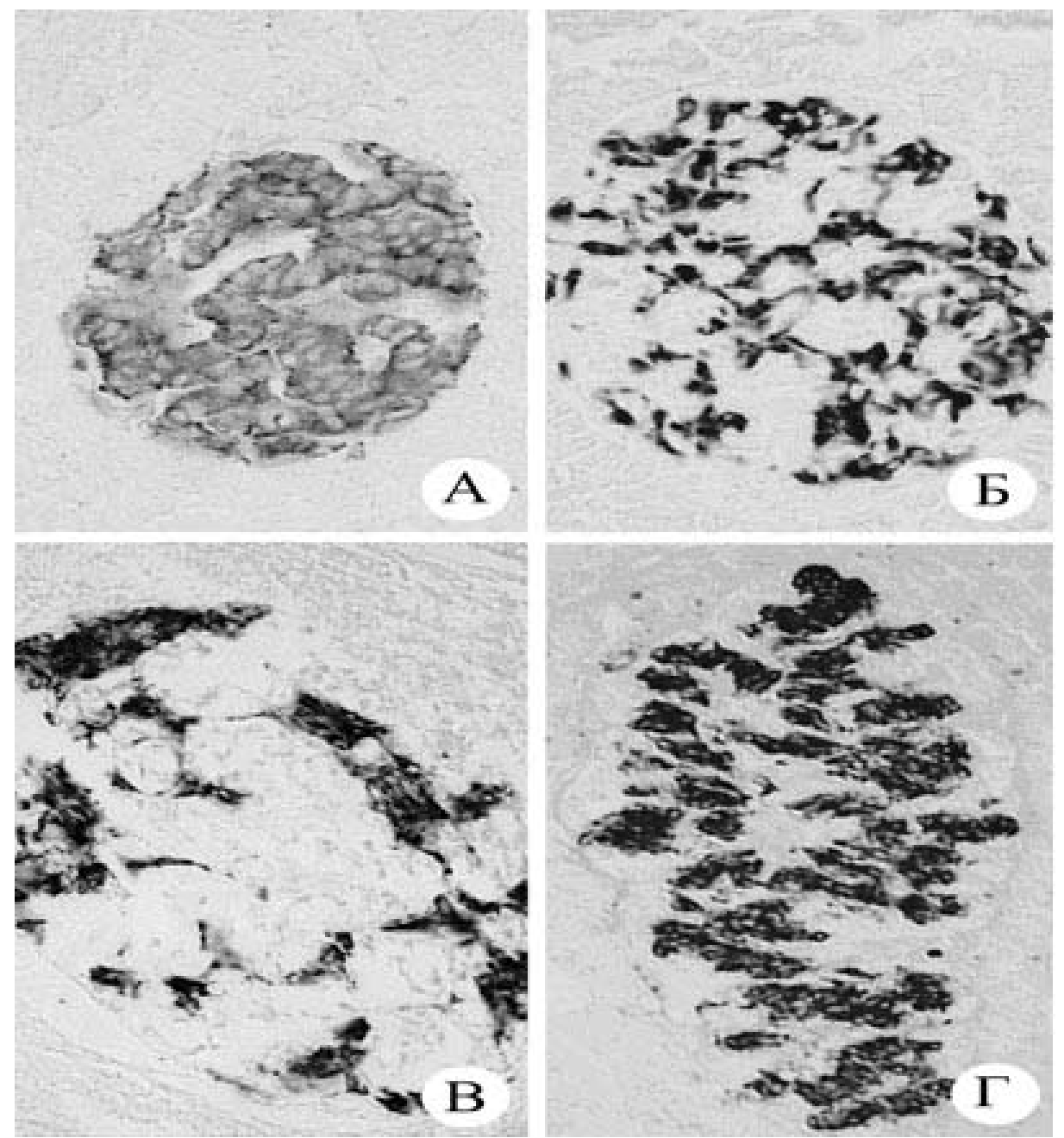

Рис. 1. Распределение инсулин-позитивных клеток в островках поджелудочной железы: А - стерляди (A. ruthenus), х40; Б - щуки обыкновенной (E. Lucius), х40; В - угря речного (A. Anguilla), х40; Г - радужная форель (S. irideus), х20.

Островки щуки преимущественно большого (до 1260 мкм диаметром) размера окружены соединительнотканной капсулой. Крупные островки могут иметь включения экзокринной ткани. В таких островках инсулин-позитивные клетки распределены по всему объему равномерно, а в небольших - сконцентрированы в центре островка. Глю- 
Российский медико-биологический вестник имени академика И.П. Павлова, №1, 2012 г.

кагон-позитивные клетки также расположены по всему островку, но их скопления превалируют на периферии. Соматостатин-позитивные клетки распределены диффузно. Следовательно у щуки выявлена тенденция формирования островков плащевого (коркового) типа, при котором глюкагон-содержащие клетки расположены на периферии, а инсулин - в центре (Рис. $1-3$, Б). 
Российский медико-биологический вестник имени академика И.П. Павлова, №1, 2012 г.
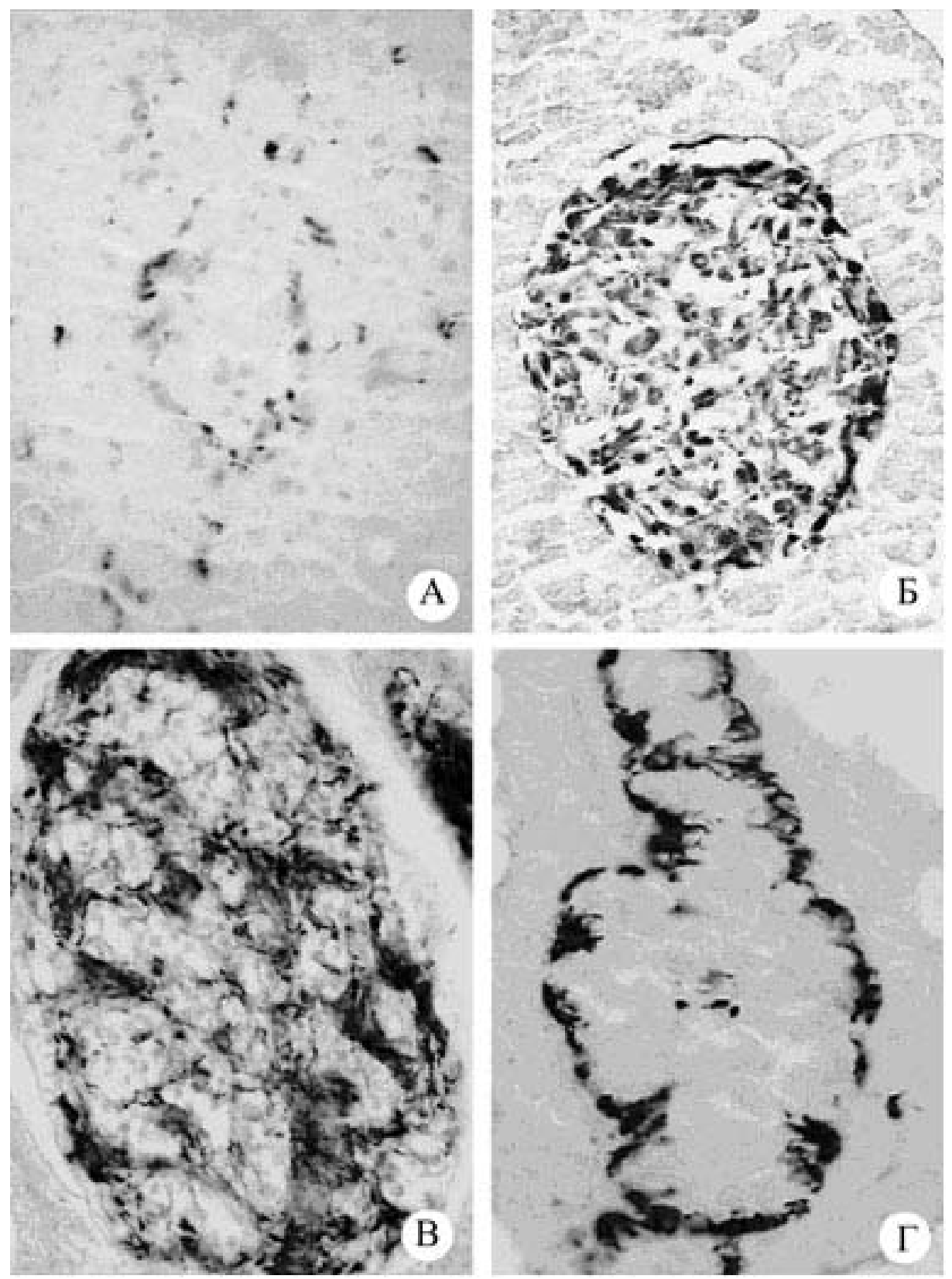
Российский медико-биологический вестник имени академика И.П. Павлова, №1, 2012 г.

Рис. 2. Распределение глюкагон-позитивных клеток в островках поджелудочной железы: А - стерляди (A. ruthenus), х40; Б - щуки обыкновенной (E. Lucius), х40; В угря речного (A. Anguilla), х40; Г- радужная форель (S. irideus), х20. 

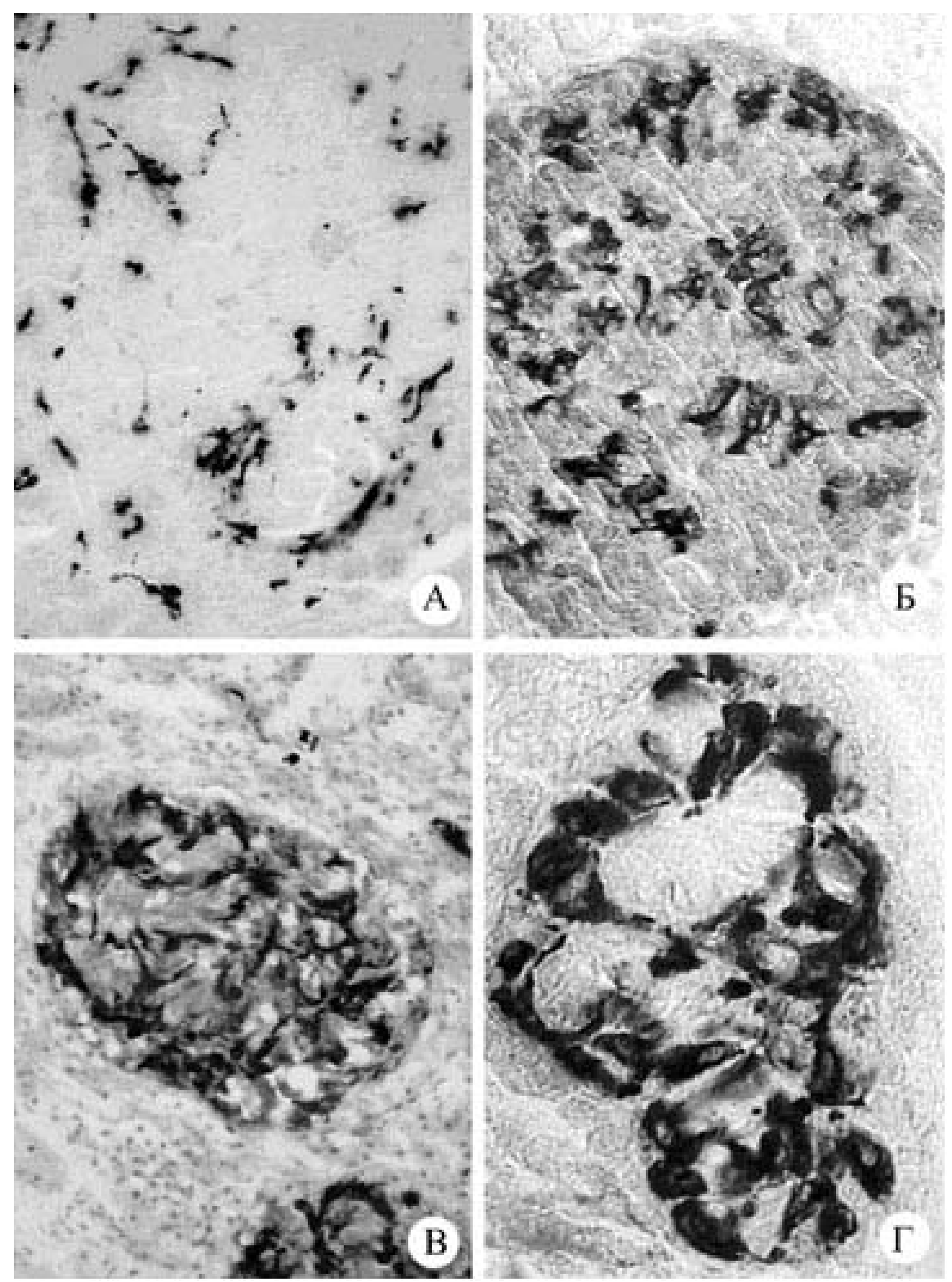

Рис. 3. Распределение соматостатин-позитивных клеток в островках поджелудочной железы: А - стерляди (A. ruthenus), х20; Б - щуки обыкновенной (E. Lucius), х40; В угря речного (A. Anguilla), х40; Г- радужная форель (S. irideus), x40. 
В группе сомовые silurids в эндокринной ткани ПЖ встречаются крупные островки, полностью или частично окруженные тонким слоем экзокринной ткани. Островки сома достигают 930 мкм в диаметре, у оринокского сома до 200 мкм, у пангасиуса до 180 мкм. Эндокринные клетки всех типов эллипсоидной формы, у сома, помимо этого имеют единственный отросток. В этой же группе островки, как и у исследованных карпообразных, имеют плащевой тип строения.

\section{Выводы}

Изученные нами лучеперые рыбы различаются как по экологии (морские, пресноводные и проходные), так и по типу питания (хищники, всеядные и растительноядные). Однако нам, как и другим авторами, не удалось выявить связи между строением эндокринной части ПЖ и образом жизни рыб. У наиболее примитивных рыб таких как таких как осетры (Acipenser), угреобразные (Anguillomorpha) и щуки (Esociformes) обнаружено диффузное распространение островков различного размера в экзокринной ткани, при этом не образуется скоплений. Радужная форель (Salmo irideus) и корюшка малоротая (Hypomesus olidus), представляющие более высокоразвитых рыб, обладают островками, собранными в особой области экзокринной ПЖ (островковом органе) предшественнике тельца Брокмана. Маленькие островки рассеяны внутри ПЖ. Подобную модель можно увидеть и у более эволюционно продвинутых карповых (Cyprinidae) и сомовых (Siluridae).

Обнаруженный полиморфизм расположения островков и формы эндокринных клеток не могут быть объяснены биологией видов и типом питания. Учитывая то, что основная функция эндокринной части ПЖ - регуляция углеводного обмена, этот вопрос требует дополнительных исследований.

\section{Литература}

1. Яглов В.В. Морфология эндокринной части поджелудочной железы костистых рыб / В.В. Яглов // Архив анатомии, гистологии и эмбриологии. 1978. - T. 74, №1. - C. 111-115.

2. Bucke D. The anatomy and histology of the alimentary tract of the carnivorous fish the pike Esox lucius L. / D. Bucke // Journal of Fish Biology. - 1971. - Vol. 3, Is. 4 - P. 421-431.

3. Epple A.E. Islet histophysiology: Evolutionary correlations / A.E. Epple, J. Brinn $/ /$ General and Comparative Endocrinology. - 1975. - Vol. 27. - P. 320-349.

4. Epple A. The Comparative Physiology of the Pancreatic Islets / A. Epple, J.E. Brinn. - Heidelberg: Springer-Verlag, 1987. - 223 p.

5. Hampson J. Law relation to animal experimentation / J. Hampson // Laboratory animals: an introduction for new experimenters / ed.: A. A. Tuffery. - Chichester, UK: J.Wiley and Sons Ltd, 1990. - P. 21-52.

6. Gastroenteropancreatic Hormones (Insulin, Glucagon, Somatostatin, and Multiple Forms of PYY) from the Pallid Sturgeon, Scaphirhynchus albus (Acipenseriformes) / J.B. Kim [et al.] // General and Comparative Endocrinology. - 2000. - Vol. 120, Is. 3. - P. 353-363.

7. Kobayashi K. Fine structure of Langerhans' islet cells in a marine teleost Conger japonicus Bleeker / K. Kobayashi, Y. Takahashi // General and Comparative Endocrinology. - 1974. - Vol. 23. - P. 1-18. 
8. Immunohistochemical study of the endocrine cells in the pancreas of the carp, Cyprinus carpio (Cyprinidae) / H.S. Kong [et al.] // Journal of Veterinary Science. 2002. - Vol. 3. - P. 303-314.

9. Different cellular distributions of two somatostatins in brain and pancreas of salmonids, and their associations with insulin- and glucagon-secreting cells / M. Nozaki [et al.] // General and Comparative Endocrinology. 1988. - Vol. 69. - P. 267-280.

10. Vincent S. The pancreas of teleostean fishes and the source of insulin / S. Vincent, E.C. Dodds, F. Dickens // Experimental Physiology. - 1925. - Vol. 15, N. 3-4. - P. 313-317.

11. Wagner G.F. Immunocytochemical localization of hormone-producing cells within the pancreatic islets of the rainbow trout (Salmo gairdneri) / G.F. Wagner, B.A. McKeown // Cell Tissue Research. 1981. - Vol. 221. - P. 181-192.

12. Immunocytochemical study of the pancreatic islets of the Pacific salmon, Oncorhynchuys kisutch / Y.-Q. Wang [et al.] // Zoology Science. - 1986. - Vol. 3. - P. 123-129.

13. The fish endocrine pancreas: Review, new data, and future research directions in ontogeny and phylogeny / J.H. Youson [et al.] // General and Comparative Endocrinology. - 2006. - Vol. 148, Is. 2. P. 105-115.

14. Youson J.H. Ontogenetic and Phylogenetic Development of the Endocrine Pancreas (Islet Organ) in Fishes / J.H. Youson, A.A. Al-Mahrouki // General and Comparative Endocrinology. - 1999. Vol. 116. - P. 303-335.

\title{
IMMUNOHISTOCHEMICAL STUDY OF THE ENDOCRINE CELLS IN THE PANCREAS OF THE ACTINOPTERYGIAN FISHES (ACTINOPTERIGII)
}

\author{
E.S. Savelieva, A.E. Proshchina
}

The endocrine tissue in the pancreas of 10 actinopterygian fishes (Actinopterigii) species was investigated in present study. Insulin-immunoreactive cells in the most of the studied species (except A. Anguilla, E. Lucius, C. Carpio) had the spherical shape. Glucagonimmunoreactive and somatostatin-immunoreactive cells had the spindle shape with cytoplasmic processes in all species. Insulin-immunoreactive cells were located in the central region of the pancreatic islets; glucagon-immunoreactive cells were located on islet periphery in the most of these species. In A. ruthenus the islets contained only insulin-positive cells. In this case glucagon-and somatostatin-positive cells were distributed around the islets, single cells and small clasters were scaterred throughout the pancreas. In the islets of A. Anguilla, insulinimmunoreactive cells were found in the peripheral region, glucagon-immunoreactive cells were located in the central region. The observed polymorphism of the islets and endocrine cells can not be explained by feeding habits of fishes.

Key words: fishes, pancreas, immunohistochemistry, islets, endocrine cells.

Савельева Екатерина Сергеевна - научный сотрудник лаборатории развития нервной системы НИИ Морфологии Человека РАМН

117418, г. Москва, ул. Цюрупы, д. 3.

E-mail: eslielsizoo@mail.ru.

Прощина Александра Евгеньевна - к.б.н., доцент, старший научный сотрудник лаборатории развития нервной системы НИИ Морфологии Человека РАМН.

117418, г. Москва, ул. Цюрупы, д. 3. 